\title{
Effects remaining after withdrawal of long-term beta-receptor blockade Reduced heart rate and altered haemodynamic response to acute propranolol administration ${ }^{1}$
}

\author{
Tomas Brundin, Olof Edhag, and Torbjörn Lundman \\ From the Departments of Clinical Physiology and Medicine, Serafimer Hospital, Karolinska Institutet, \\ S-112 83 Stockholm, Sweden
}

Central haemodynamics at rest and during exercise were studied in 14 male patients with moderate essential hypertension. Their circulatory state was studied before and immediately after intravenous administration of propranolol, $0.2 \mathrm{mg} / \mathrm{kg}$ body weight. In 8 of the patients an identical study was repeated after $\geq 2$ months of oral propranolol therapy. This second study was performed when the oral therapy had been discontinued for $\geq 72$ hours which exceeds the time necessary for complete metabolism and excretion of propranolol. Pulmonary oxygen uptake, arteriovenous oxygen difference, heart rate, and blood pressures in the subclavian artery, pulmonary artery, pulmonary wedge position, and right atrium were measured.

Before oral treatment, propranolol injection caused significant reductions of oxygen uptake ( 5\%), heart rate $(\sim 13 \%)$, cardiac output $(\sim 20 \%)$, and stroke volume $(\sim 10 \%)$, significant increments to systemic $(\sim 35 \%)$ and pulmonary vascular resistance ( $\sim 35 \%)$, and increased filling pressures for both ventricles during exercise. After long-term treatment and omission of the drug, the spontaneous heart rates at rest and during exercise were significantly lower than before treatment. Propranolol injection now still increased the ventricular filling pressures at exercise but caused no significant effects on oxygen uptake, heart rate, cardiac output, stroke volume, or systemic vascular resistance.

It is concluded that long-term beta-receptor blockade leads to a physiological adaptation including a persistent relative bradycardia and almost complete abolition of the haemodynamic response to acute administration of a beta-receptor blocking agent. It is suggested that this adaptation, which resembles that of physical training, constitutes one mechanism whereby long-term beta-receptor blockade is able to reduce the arterial blood pressure.

Although beta-adrenergic blocking drugs have been frequently used for treatment of arterial hypertension in recent years, it seems that the mechanisms underlying the observed antihypertensive effect are still not fully understood. Several investigations have shown that the fall in cardiac output and heart rate at acute inhibition of the beta-receptors is fully compensated for by a reflexogenic rise in systemic vascular resistance, which prevents any blood

Received 18 February 1976.

1This investigation was supported by grants from the Swedish Association against Heart and Chest Diseases, Stiftelsen Lars Hiertas Minne, Carl Yngve Johnson's Foundation, Wesséns Foundation, and ICI-Pharma AB, Gothenburg, Sweden pressure fall (Frohlich et al., 1968; Ulrych et al., 1968 and others). The desired reduction in blood pressure has been found to require a prolonged beta-receptor blockade, extended over weeks or months (Prichard and Gillam, 1969; Tibblin and Áblad, 1969; Tarazi and Dustan, 1972 and others). Thus, the antihypertensive effect is not directly bound to the pharmacological action of blocking the beta-adrenergic receptors, but rather represents one feature in a pattern of physiological reset mechanisms occurring in response to prolonged betareceptor blockade (cf. Prichard and Gillam, 1966; Frohlich et al., 1968). However, up till now our knowledge about long-term effects of beta-receptor 
TABLE 1 Anthropometric data, blood volume calculated from body size ( $\left.B V_{\text {calc }}\right)$, blood volume observed $\left(B V_{\mathrm{obs}}\right)$, heart volume $(H V)$, and sphygmomanometric blood pressures (BP) obtained before the study started in $I: 14$ patients investigated before long-term treatment with propranolol, II: 8 patients investigated both before and after long-term treatment with propranolol

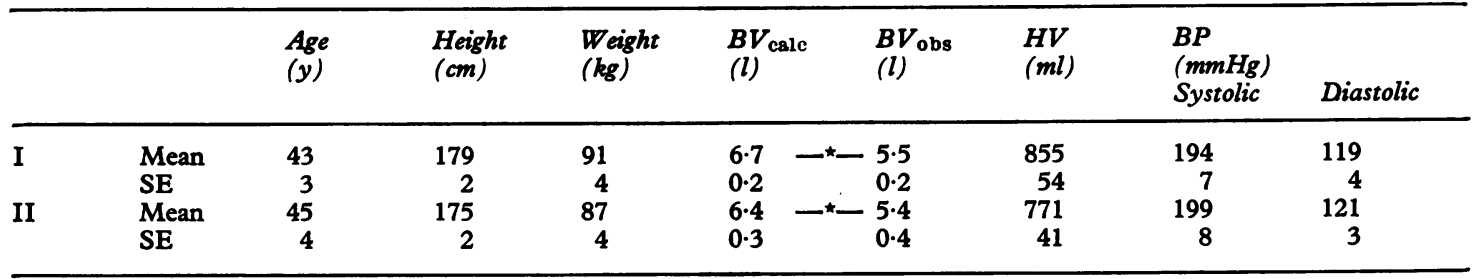

$\star \mathbf{P}<0.001$.

blockade is sparse and it is now known for certain whether any delayed haemodynamic effects remain after withdrawal of prolonged beta-blocking therapy.

In the present investigation the acute haemodynamic effects of intravenous propranolol administration were studied in hypertensive patients before and after long-term oral treatment with the drug. In order to isolate delayed effects, the second study was performed after omission of the oral medication.

\section{Subjects and methods}

Fourteen male patients aged 19 to 55 years with slight to moderate arterial hypertension were studied. They were informed of the nature, purpose, and possible risks involved in the study before giving their voluntary consent to participate. Anthropometric data, circulatory dimensions, and sphygmomanometric blood pressures obtained at the out-patient clinic before admission for the haemodynamic studies are given in Table 1 . All the patients had 'primary hypertension' group I-II according to the WHO classification. Seven of them had never been treated with antihypertensive drugs. The others had received various antihypertensive treatment for short periods. In only 2 patients had beta-blocking drugs been used earlier, the treatment being terminated several months before this study was undertaken. None of the patients had any known renal disease or showed significantly reduced creatinine clearance. Neither was there any history of angina pectoris. All the patients had normal electrocardiograms both at rest and during heavy exercise. Physical working capacity was within normal limits. Eleven of the patients were overweight by 13 to 65 per cent (according to Metropolitan Life Insurance Tables, 1959). Consequently, the circulatory dimensions represented by the blood volume, total haemoglobin, and heart volume were

significantly smaller than those calculated according to body size (cf. Sjöstrand, 1949). In relation to total haemoglobin the heart volumes were all within normal limits (Kjellberg, Rudhe, and Sjöstrand, 1949; Holmgren and Ovenfors, 1960).

The patients were admitted to the hospital 1 to 3 days before the first haemodynamic study. After this the long-term oral propranolol therapy was instituted and the patients were checked regularly in the out-patient clinic. Their daily doses of propranolol ranged between 160 and $640 \mathrm{mg}$. The blood pressure reaction to this therapy, as judged from sphygmomanometric measurements, was a significant reduction of both systolic and diastolic pressure. Eight of the patients accepted an additional haemodynamic study after the long-term treatment for 2 to 9 months. The trial design is presented in Fig. 1. At admission after the oral treatment the sphygmomanometric arterial pressures were significantly reduced $(P<0.05)$, now being only slightly raised $(\sim 155 / 95 \mathrm{mmHg}(20.6 /$ $12.6 \mathrm{kPa})$ compared with $\sim 200 / 120 \mathrm{mmHg}(26.6 /$ $16.0 \mathrm{kPa}$ ) before treatment). At admission the therapy was discontinued immediately. The patients had no drugs for $\geq 72$ hours before the second haemodynamic study was performed. During the

\begin{tabular}{|l|l|l|}
\hline 1 - 3 days & \multicolumn{1}{|c|}{$2-9$ months } & \multicolumn{1}{|c|}{3 days } \\
\hline $\begin{array}{l}\text { in hospital } \\
\text { without } \\
\text { medication }\end{array}$ & $\begin{array}{l}\text { on oral propranolol } \\
\text { treatment } 160-640 \mathrm{mg} \\
\text { daily; followed at } \\
\text { outpatient clinic }\end{array}$ & $\begin{array}{l}\text { in hospital } \\
\text { without } \\
\text { propranolol }\end{array}$ \\
\hline
\end{tabular}

(1) haemodynamic study before and after propranolol intravenously (14 patients)

FIG. 1 Trial design. 
time after omission of the drug the blood pressure was measured repeatedly; none of the patients showed any abrupt pressure rise in direct response to this omission of the drug.

Blood volume was determined by conventional ${ }^{131}$ I-albumin technique (Fine and Seligman, 1943; Pritchard, Moir, and MacIntyre, 1955). Heart volume was determined by the two-plane $x$-ray method, performed with the patient supine (Larsson and Kjellberg, 1948). Sphygmomanometric blood pressure was measured according to the Korotkow method, diastolic value noted at phase 5 .

\section{Haemodynamic studies}

A radio-opaque 'teflon' catheter $(1.2 \mathrm{~mm}$ outer diameter) was inserted percutaneously under local anaesthesia into the left brachial artery and passed to a tip position in the subclavian artery. A double lumen catheter (Swan-Ganz 7F, Edwards Laboratories) was inserted percutaneously into an antecubital vein and passed to the pulmonary artery under fluoroscopic guidance. Pulmonary oxygen uptake, arteriovenous oxygen difference, heart rate, and blood pressures were measured at rest and during bicycle exercise of 7 minutes at work loads preset individually to increase heart rate to about 120 to 130 beats/min. The entire procedure was performed with the patients in supine body position. After a resting period of 20 to 30 minutes, baseline measurements were repeated and propranolol was then given intravenously $(0.2 \mathrm{mg} / \mathrm{kg}$ body weight). After a further 7-minute period, the resting measurements and the exercise programme were repeated.

\section{Technical procedures}

The expired air was collected in Douglas bags for determination of pulmonary oxygen uptake (Scholander, 1947). Blood samples were drawn from the pulmonary and brachial arteries for analysis of oxygen content (Holmgren and Pernow, 1959). Cardiac output was calculated by the direct Fick method. The expired air was collected for 5 minutes at rest and for 3 minutes during exercise. Blood pressures were recorded in the subclavian artery, in the pulmonary wedge position, in the pulmonary artery, and in the right atrium by means of electrical transducers (EMT 34 and 35, Elema) and referred to standard water columns corresponding to 20,50 , and $100 \mathrm{mmHg}(2.7,6.7$, and $13.3 \mathrm{kPa})$, respectively. Systemic vascular resistance was calculated as the ratio between the mean blood pressure fall from the subclavian artery to the right atrium and the value for cardiac output. The pulmonary vascular resistance was calculated similarly using the mean pressure fall from the pulmonary artery

TABLE 2 Haemodynamic results from 14 male hypertensive patients at rest, during exercise, and 20 minutes after exercise without pretreatment and at rest and during exercise after intravenous administration of propranolol $(0 \cdot 2 \mathrm{mg} / \mathrm{kg}$ b.w.) (mean $\pm S E M)$

\begin{tabular}{|c|c|c|c|c|c|}
\hline & \multicolumn{3}{|c|}{ No treatment } & \multicolumn{2}{|c|}{ During beta-receptor blockade } \\
\hline & Rest & Exercise & $\begin{array}{l}\text { Rest } 20 \text { minutes } \\
\text { after exercise }\end{array}$ & Rest & Exercise \\
\hline $\begin{array}{l}\text { Oxygen uptake }(\mathrm{ml} / \mathrm{min}) \\
\text { Arteriovenous } \mathrm{O}_{2} \mathrm{diff} .(\mathrm{ml} / 1) \\
\text { Cardiac output }(1 / \mathrm{min}) \\
\text { Heart rate (beats } / \mathrm{min}) \\
\text { Stroke volume }(\mathrm{ml}) \\
\text { Vasc. resist. }(\mathrm{mmHg} / 1 / \mathrm{min})\end{array}$ & $\begin{aligned} 319 & \pm 14 \\
49 & \pm 2 \\
6 \cdot 7 & \pm 0 \cdot 5 \\
74 & \pm 4 \\
93 & \pm 7\end{aligned}$ & $\begin{aligned} 1279 & \pm 77 \\
103 & \pm 3 \\
12 \cdot 5 & \pm 0 \cdot 7 \\
120 & \pm 5 \\
108 & \pm 7\end{aligned}$ & $\begin{aligned} 325 & \pm 11 \\
51 & \pm 2 \\
6 \cdot 6 & \pm 0 \cdot 5 \\
66 & \pm 3 \\
98 & \pm 7\end{aligned}$ & $\begin{aligned} 301 & \pm 14 \\
58 & \pm 2 \\
5 \cdot 4 & \pm 0 \cdot 4 \\
65 & \pm 1 \\
83 & \pm 5\end{aligned}$ & $\begin{array}{l}1214 \pm 82 \\
129 \pm 5 \\
9 \cdot 5 \pm 0 \cdot 6 \\
99 \pm 3 \\
96 \pm 6\end{array}$ \\
\hline $\begin{array}{l}\text { Systemic } \\
\text { Pulmonary }\end{array}$ & $\begin{array}{l}18 \pm 1 \\
0 \cdot 8 \pm 0 \cdot 1\end{array}$ & $\begin{aligned} 11 & \pm 1 \\
0.9 & \pm 0.1\end{aligned}$ & 二 & $\begin{aligned} 23 & \pm 2 \\
1 \cdot 1 & \pm 0 \cdot 1\end{aligned}$ & $\begin{aligned} 14 & \pm 1 \\
1 \cdot 2 & \pm 0 \cdot 1\end{aligned}$ \\
\hline \multicolumn{6}{|l|}{$\begin{array}{l}\text { Blood pressure (mmHg) } \\
\text { Subclav. artery }\end{array}$} \\
\hline $\begin{array}{l}\text { Systolic } \\
\text { Diastolic } \\
\text { Mean } \\
\text { Pulm. artery }\end{array}$ & $\begin{array}{r}159 \pm 5 \\
99 \pm 3 \\
124 \pm 4\end{array}$ & $\begin{array}{l}182 \pm 6 \\
108 \pm 4 \\
142 \pm 5\end{array}$ & - & $\begin{array}{l}163 \pm 6 \\
101 \pm 3 \\
126 \pm 4\end{array}$ & $\begin{array}{l}177 \pm 4 \\
103 \pm 3 \\
133 \pm 3\end{array}$ \\
\hline $\begin{array}{l}\text { Systolic } \\
\text { Diastolic } \\
\text { Mean } \\
\text { Pulm. wedge }\end{array}$ & $\begin{array}{l}24 \pm 2 \\
12 \pm 1 \\
17 \pm 1\end{array}$ & $\begin{array}{l}45 \pm 3 \\
22 \pm 2 \\
33 \pm 2\end{array}$ & - & $\begin{array}{l}25 \pm 2 \\
12 \pm 1 \\
18 \pm 2\end{array}$ & $\begin{array}{l}52 \pm 3 \\
29 \pm 2 \\
39 \pm 2\end{array}$ \\
\hline $\begin{array}{l}\text { Mean } \\
\text { Right atrium }\end{array}$ & $12 \pm 1$ & $21 \pm 2$ & - & $12 \pm 1$ & $27 \pm 2$ \\
\hline Mean & $6 \pm 1$ & $8 \pm 1$ & 一 & $7 \pm 0$ & $12 \pm 1$ \\
\hline
\end{tabular}

Conversion from Traditional Units to SI Units: $1 \mathrm{mmHg} \approx 0.133 \mathrm{kPa}$. 
to the pulmonary wedge position. The midthoracic height was used as zero pressure level. The pressure traces were recorded on an ultraviolet beam writer (Ultralette, ABEM 5650). Heart rate was recorded continuously by electrocardiography. The room temperature was kept at about $23^{\circ} \mathrm{C}$. Standard statistical methods were employed (Snedecor and Cochran, 1967), the paired t-test being used when applicable. Data in the text, tables, and figures are reported as mean \pm standard error of mean.

\section{Results}

I: Fourteen patients studied before long-term oral treatment

Haemodynamic status Data obtained at rest and during exercise are given in Table 2. The normal limits from the material published by Ekelund and Holmgren (1967) have been used for reference.

At rest pulmonary oxygen uptake exceeded estimates based on age and body size by about 24 per cent. In relation to oxygen uptake the mean values for arteriovenous oxygen difference and cardiac output were within the normokinetic limits. In relation to cardiac output, the mean values for systolic, diastolic, and mean pressures in the sub-

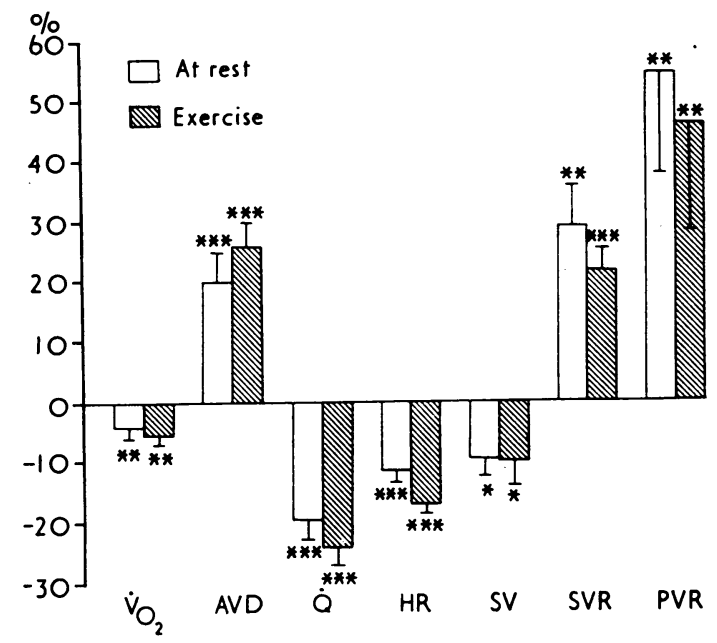

FIG. 2 Acute effects of intravenous propranolol $\left(0.2 \mathrm{mg} / \mathrm{kg}\right.$ b.w.) on pulmonary oxygen uptake $\left(\dot{\mathrm{V}}_{\mathrm{or}}\right)$, arteriovenous oxygen difference (AVD), cardiac output $(\dot{Q})$, heart rate $(H R)$, stroke volume $(S V)$, systemic vascular resistance (SVR), and pulmonary vascular resistance (PVR) at rest and during exercise in 14 male hypertensive patients. Mean percentage effects. Bars indicate SEM. Asterisks indicate statistical significance for each column. clavian artery considerably exceeded the normal values. Thus, the mean calculated systemic vascular resistance was enhanced. The filling pressures for both the ventricles were within the normal variations, as were the systolic and mean pressures in the pulmonary artery.

During exercise mean oxygen uptake showed a fourfold increase. The mean rise in arteriovenous oxygen difference and cardiac output were within the normal range. All the patients thus fell within the normokinetic limits. The stroke volume increased significantly, by about 16 per cent compared with resting values. The pressures in the subclavian artery showed only minimum changes comparea with those at rest, still being higher than normal in relation to cardiac output. The mean systemic vascular resistance was lower than at rest, but still higher than normal. In the pulmonary artery the systolic, mean, diastolic, and wedge pressures rose above the normal limits. The mean filling pressure for the right ventricle was maintained at an ordinary level.

Acute effects of intravenous propranolol administration Data are presented in Table 2 and Fig. 2

After administration of propranolol cardiac output was considerably reduced. This effect was most pronounced during exercise, both in absolute values and in relation to oxygen uptake. The magnitude of the cardiac output suppression was similar to that described previously (Åström, 1968).

The oxygen uptake was significantly reduced by about 5 per cent at propranolol injection both at rest and during exercise. A similar effect was found in healthy individuals (Brundin, to be published). The heart rate was significantly retarded, most conspicuously during exercise $(-17 \%)$.

The stroke volume was significantly smaller $(-10 \%)$ after propranolol. This effect was noted even during exercise, in contrast to previous results in healthy subjects and in patients with angina pectoris (cf. Aström, 1968). However, the exerciseinduced increase in stroke volume (about 14\%) was still found after propranolol.

Systemic vascular resistance was considerably increased after propranolol injection both at rest $(\sim 28 \%)$ and during exercise $(\sim 22 \%)$. The pressure in the systemic artery was not significantly affected by propranolol at rest. During exercise the mean arterial pressure was lower $(-7 \%)$ after propranolol. At rest the pressures in the pulmonary artery, pulmonary wedge position, and right atrium were essentially unaffected by propranolol. During exercise, however, the filling pressures for both the 
TABLE 3 Haemodynamic results obtained before and after i.v. administration of propranolol $0.2 \mathrm{mg} / \mathrm{kg}$ b.w. in 8 male hypertensive patients before and after long-term oral therapy with propranolol (mean values $\pm S E$ )

\begin{tabular}{|c|c|c|c|c|c|c|c|c|}
\hline & \multicolumn{4}{|c|}{$\begin{array}{l}\text { Before long-term treatment } \\
\text { Rest Exe }\end{array}$} & \multicolumn{4}{|c|}{ After long-term treatment } \\
\hline & Spontaneous & $\begin{array}{l}\text { After } \\
\text { propranolol }\end{array}$ & Spontaneous & $\begin{array}{l}\text { After } \\
\text { propranolol }\end{array}$ & Spontaneous & $\begin{array}{l}\text { After } \\
\text { propranolol }\end{array}$ & Spontaneous & $\begin{array}{l}\text { After } \\
\text { propranolol }\end{array}$ \\
\hline $\begin{array}{l}\text { Oxygen uptake }(\mathrm{ml} / \mathrm{min}) \\
\text { Arteriovenous } \mathrm{O}_{2} \text { diff. } \\
(\mathrm{ml} / \mathrm{l})\end{array}$ & $\begin{array}{c}322 \pm 22 \\
46 \pm 2\end{array}$ & $\begin{aligned} 311 & \pm 18 \\
58 & \pm 3\end{aligned}$ & $\begin{array}{c}1268 \pm 130 \\
105 \pm 4\end{array}$ & $\begin{aligned} 1215 & \pm 139 \\
129 & \pm 8\end{aligned}$ & $\begin{array}{c}296 \pm 12 \\
53 \pm 4\end{array}$ & $\begin{array}{c}292 \pm 12 \\
56 \pm 3\end{array}$ & $\begin{array}{c}1287 \pm 125 \\
114 \pm 5\end{array}$ & $\begin{array}{c}1260 \pm 141 \\
125 \pm 5\end{array}$ \\
\hline $\begin{array}{l}\text { Cardiac output }(1 / \mathrm{min}) \\
\text { Heart rate (beats } / \mathrm{min}) \\
\text { Stroke volume }(\mathrm{ml}) \\
\text { Vasc. resist. }(\mathrm{mmHg} / 1 / \mathrm{min})\end{array}$ & $\begin{array}{l}7 \cdot 3 \pm 0 \cdot 7 \\
83 \pm 5 \\
91 \pm 10\end{array}$ & $\begin{array}{l}5 \cdot 5 \pm 0 \cdot 5 \\
71 \pm 4 \\
78 \pm 6\end{array}$ & $\begin{array}{c}12 \cdot 0 \pm 0 \cdot 9 \\
130 \pm 5 \\
95 \pm 8\end{array}$ & $\begin{array}{l}9 \cdot 5 \pm 1 \cdot 0 \\
105 \pm 4 \\
88 \pm 8\end{array}$ & $\begin{array}{l}6 \cdot 0 \pm 0 \cdot 4 \\
66 \pm 4 \\
95 \pm 9\end{array}$ & $\begin{array}{l}5 \cdot 4 \pm 0 \cdot 4 \\
64 \pm 3 \\
87 \pm 10\end{array}$ & $\begin{array}{l}11 \cdot 3 \pm 0 \cdot 9 \\
105 \pm 6 \\
110 \pm 9\end{array}$ & $\begin{array}{c}10 \cdot 1 \pm 1 \cdot 1 \\
94 \pm 2 \\
105 \pm 10\end{array}$ \\
\hline $\begin{array}{l}\text { Systemic } \\
\text { Pulmonary }\end{array}$ & $\begin{aligned} 18 & \pm 2 \\
0.7 & \pm 0 \cdot 1\end{aligned}$ & $\begin{array}{l}26 \pm 3 \\
1 \cdot 1 \pm 0 \cdot 2\end{array}$ & $\begin{array}{l}12 \pm 1 \\
0.8 \pm 0 \cdot 1\end{array}$ & $\begin{aligned} 15 & \pm 2 \\
1 \cdot 1 & \pm 0 \cdot 1\end{aligned}$ & $\begin{aligned} 20 & \pm 2 \\
0.9 & \pm 0 \cdot 1\end{aligned}$ & $\begin{array}{c}23 \pm 3 \\
1 \cdot 3 \pm 0 \cdot 2\end{array}$ & $\begin{array}{c}13 \pm 1 \\
1 \cdot 1 \pm 0 \cdot 2\end{array}$ & $\begin{array}{c}14 \pm 2 \\
1 \cdot 2 \pm 0 \cdot 2\end{array}$ \\
\hline $\begin{array}{l}\text { Blood pressure (mmHg) } \\
\text { Subclav. artery }\end{array}$ & & & & & & & & \\
\hline $\begin{array}{l}\text { Systolic } \\
\text { Diastolic } \\
\text { Mean }\end{array}$ & $\begin{array}{r}158 \pm 7 \\
98 \pm 5 \\
126 \pm 5\end{array}$ & $\begin{array}{l}172 \pm 7 \\
107 \pm 4 \\
133 \pm 5\end{array}$ & $\begin{array}{l}188 \pm 8 \\
113 \pm 6 \\
144 \pm 7\end{array}$ & $\begin{array}{l}181 \pm 5 \\
104 \pm 3 \\
134 \pm 4\end{array}$ & $\begin{aligned} 154 & \pm 8 \\
94 & \pm 5 \\
119 & \pm 7\end{aligned}$ & $\begin{aligned} 161 & \pm 15 \\
97 & \pm 8 \\
121 & \pm 9\end{aligned}$ & $\begin{array}{l}187 \pm 10 \\
102 \pm 6 \\
139 \pm 8\end{array}$ & $\begin{array}{l}181 \pm 11 \\
102 \pm 6 \\
133 \pm 8\end{array}$ \\
\hline Pulm. artery & & & & & & & & \\
\hline $\begin{array}{l}\text { Systolic } \\
\text { Diastolic } \\
\text { Mean }\end{array}$ & $\begin{array}{l}23 \pm 2 \\
11 \pm 1 \\
16 \pm 2\end{array}$ & $\begin{array}{l}26 \pm 4 \\
12 \pm 2 \\
18 \pm 2\end{array}$ & $\begin{array}{l}42 \pm 4 \\
21 \pm 3 \\
31 \pm 3\end{array}$ & $\begin{array}{l}52 \pm 4 \\
29 \pm 2 \\
39 \pm 3\end{array}$ & $\begin{array}{l}26 \pm 2 \\
12 \pm 1 \\
18 \pm 1\end{array}$ & $\begin{array}{l}26 \pm 2 \\
11 \pm 1 \\
18 \pm 2\end{array}$ & $\begin{array}{l}44 \pm 4 \\
20 \pm 2 \\
32 \pm 3\end{array}$ & $\begin{array}{l}47 \pm 3 \\
25 \pm 2 \\
37 \pm 3\end{array}$ \\
\hline $\begin{array}{l}\text { Pulm. wedge } \\
\text { Mean } \\
\text { Right atrium }\end{array}$ & $10 \pm 2$ & $11 \pm 3$ & $20 \pm 4$ & $27 \pm 2$ & $11 \pm 1$ & $12 \pm 1$ & $18 \pm 4$ & $25 \pm 2$ \\
\hline Mean & $6 \pm 1$ & $7 \pm 0$ & $8 \pm 1$ & $13 \pm 1$ & $6 \pm 1$ & $6 \pm 1$ & $7 \pm 1$ & $12 \pm 1$ \\
\hline
\end{tabular}

ventricles rose above normal limits, significantly more than before propranolol, as did the systolic and mean pressures in the pulmonary artery. Thus, the acute effects of propranolol could be summarized as follows: (a) reduction of oxygen uptake, cardiac output, heart rate, and stroke volume; (b) further increase of systemic and pulmonary vascular resistance; (c) increase of the pressures in the pulmonary artery and of the filling pressures for both ventricles during exercise.

\section{II: Eight patients studied before and after long-term oral therapy with propranolol}

The haemodynamic status did not differ significantly from that found in the larger group. Data are given in Table 3 and Fig. 3 and 4. Thus, the systemic vascular resistance and arterial blood pressures were raised both at rest and during exercise and the filling pressure for the left ventricle rose steeply during exercise.

The acute effects of propranolol injection were also essentially identical with those in the larger group.

After long-term treatment the spontaneous heart rates at rest and during exercise were significantly lower $(P<0.05)$ than before oral treatment. The mean values for pulmonary oxygen uptake, cardiac

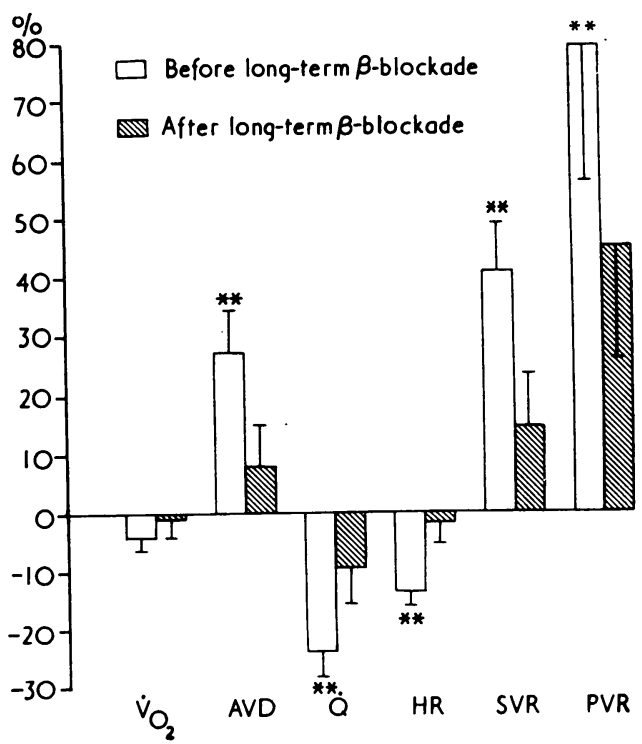

FIG. 3 Acute haemodynamic effects of intravenous propranolol $(0.2 \mathrm{mg} / \mathrm{kg} \mathrm{b.w.)}$ at rest in 8 male hypertensive patients studied before and after long-term oral propranolol therapy. Mean percentage effects. Bars indicate SEM. Abbreviations as in Fig. 2. Asterisks indicate statistical significance for each column. 
output, and arterial blood pressures tended to be somewhat lower than before the long-term treatment, but none of these variables had changed significantly during the period of oral beta-receptor blockade. Neither was vascular resistance altered compared with the pretreatment investigation.

Intravenous injection of propranolol now caused only minor haemodynamic effects, none of which attained statistical significance at rest. During exercise, propranolol injection caused slight and nonsignificant reductions in cardiac output and mean arterial blood pressure. Neither was the systemic vascular resistance significantly changed by propranolol injection (Fig. 4). However, during exercise the filling pressures for both ventricles increased in response to the intravenous betablockade in a similar way to that observed before long-term treatment (Table 3). However, most of the acute haemodynamic effects of intravenous propranolol injection were considerably reduced or abolished after long-term treatment with the drug.

\section{Discussion}

The present investigation was undertaken in order to study acute and any chronic effects of betaadrenergic receptor blockade. The study was designed to find out whether any haemodynamic effects persisted after a period of long-term receptor blockade and whether the acute effects of propranolol administration were different or modified

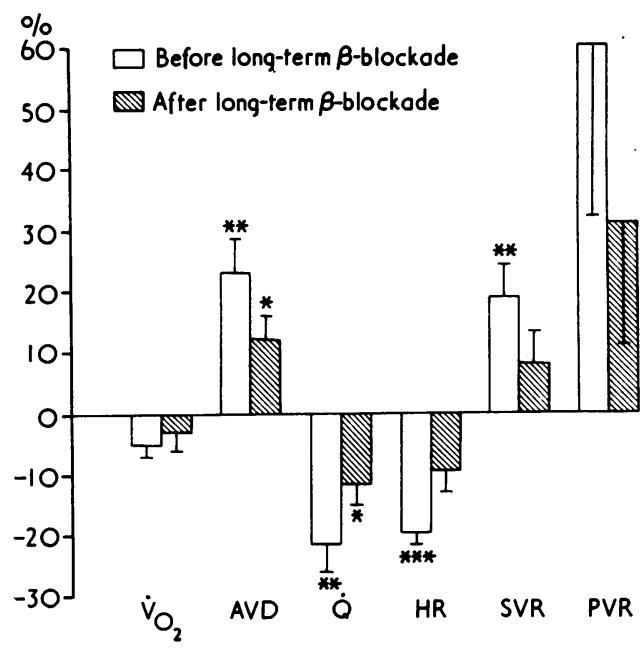

FIG. 4 Acute haemodynamic effects of intravenous propranolol ( $0.2 \mathrm{mg} / \mathrm{kg}$ b.w.) during exercise in 8 male hypertensive patients studied before and after longterm oral propranolol therapy. Mean percentage effects. Bars indicate SEM. Abbreviations as in Fig. 2 and 3. Asterisks indicate statistical significance for each column. after the long-term treatment.

The patients in this study were all young or middle-aged men with slight or moderate essential hypertension. All except three had an increased body weight. Apart from the high arterial pressure and systemic vascular resistance, their haemodynamic status was normal compared with previously published normal materials (Ekelund and Holmgren, 1967).

The acute haemodynamic effects in response to propranolol injection before long-term treatment with the drug could be explained easily in most respects as secondary to the well-known negative chronotropic and inotropic effects that occur in immediate response to inhibition of the betaadrenergic receptors of the heart (Nickerson, 1949). The negative chronotropic effect reduces cardiac output provided there is no compensatory increase in stroke volume. Such an increase will probably be prevented by the concomitant negative inotropic effect. In the present study propranolol led to a significant reduction of stroke volume. Cardiac output consequently decreased. A simultaneous reduction of heart rate and cardiac output leads to less frequent and weaker stimuli to the baroreceptors. Thereby the afferent discharge frequency in the depressor nerves will fall. It is well known that such a reduction of this particular afferent nervous activity constitutes the adequate stimulus for the pressor area of the vasomotor centre and leads to an accelerated impulse traffic in the sympathetic nerves, increasing the release of noradrenaline at the nerve endings (for references see recent review by Sleight, 1975). The $\alpha$-receptors of the resistance vessels will react to the increased stimulation and the peripheral vascular resistance will rise, thus preventing the fall of the mean arterial blood pressure which would otherwise follow a reduction of cardiac output.

During dynamic exercise, when the blood vessels in the muscles dilate and general vascular resistance falls, extra demands for an effective baroreceptor function will arise if the normal capacity for increasing cardiac output is impaired. Consequently, one would expect the mean arterial blood pressure to fall at exercise after propranolol administration: this it did significantly. A further physiological consequence of physical exercise is an increased return of venous blood to the heart. If the primary effect of beta-adrenergic inhibition is a depressant action on both the frequency and the force of the heart, the filling pressures would be expected to rise during exercise after propranolol administration: this they did considerably. These higher filling pressures had the secondary effect of facilitating the ventricular filling, which might well explain why the 
stroke volume rose in response to exercise even after propranolol injection. This effect was probably a result of the Frank-Starling mechanism, which would not be interfered with by the negative inotropic effect of the drug.

The significant increase in pulmonary vascular resistance which followed beta-receptor blockade both at rest and during exercise seems difficult to explain. Pulmonary dynamics, which might be involved in the mechanisms underlying regulation of vascular resistance, were not analysed in this study. Arterial oxygen saturation did not, however, change after propranolol.

In accordance with the view presented above, a therapeutic beta-receptor inhibition would, if extended over long periods, constitute a chronic load on the baroreceptor reflex mechanisms. Thus, a steady and intense stimulation would be directed from the vasomotor centre to the sympathetic nerves and further onto the adrenergic receptors. It is well known that most neurophysiological systems react to a long-lasting stimulation by some kind of adaptation (cf. Adair and Manning, 1975). It seems unlikely that such a complex neuronal and neurohumoral chain as that from the baroreceptors via the vasomotor centre and the sympathetic pre- and postganglionic neurons to the adrenergic receptors would be completely devoid of adaptive functions. However, during beta-receptor blockade of the heart, any adaptation in the afferent part of the baroreceptor reflex would not seem to be of much interest, since the cardiac effects at propranolol injection all constitute negative stimuli with regard to the baroreceptor as well as the afferent depressor nerve function. On the other hand, any adaptive mechanisms within the central relay neurons and/or in the sympathetic nerves would be relevant here. Even at receptor level, continuous neurohumoral stimulation has been shown to induce a subsensitivity (for ref. see Furchgott, 1972).

Such an adaptation in the vasomotor regulation system, which would be difficult to show directly in man, might well be a conceivable mechanism whereby the beta-receptor blocking drugs are able to reduce the arterial blood pressure. Some adaptive function has previously been suggested as the mechanism for the antihypertensive effect of betareceptor blocking drugs (cf. Prichard and Gillam, 1966; Frohlich et al., 1968; Tarazi and Dustan, 1972). The direct action of beta-receptor inhibition can never be expected to, and has never been shown to, reduce the blood pressure. It is known that longterm therapy is required before the blood pressure reduction appears (Prichard and Gillam, 1969 and others). This fact agrees with the view that a vegetative adaptation is needed to induce the hypotensive effects of beta-receptor blocking drugs.

The present results show that long-term inhibition of human beta-adrenergic receptors leads to an adaptation process, at least in those adrenergic mechanisms which are mediated by the 'beta side' of the receptor. This adaptation remains after the drug has been omitted, metabolized, and excreted. The persistent effects, which have not been described previously, appeared as: (1) a considerable reduction of heart rate; (2) an almost total lack of acute haemodynamic response to intravenous propranolol administration.

Both these effects were demonstrable at rest as well as during exercise. The spontaneous heart rate at rest was thus significantly lowered at the reinvestigation. The magnitude of this reduction, which occurred during and persisted after the long-term therapy, corresponds to that observed after longlasting and intense physical training. The possible mechanisms whereby the heart rate can be depressed if not parallelled by increased dimensions of the central circulation, are either an increased parasympathetic or a decreased sympatho-adrenal influence on the heart. The finding that intravenous injection of propranolol did not change the heart rate significantly indicates that it was the sympathoadrenal part of the autonomic heart rate regulation that was changed, either in the form of a reduced basal sympatho-adrenal activity or, perhaps, in the form of a persistent reduction of the sensitivity of the beta-adrenergic receptors of the heart. A reduced receptor sensitivity has been shown to occur after intense physical training (Brundin and Cernigliaro, 1975). In extremely well-trained athletes, beta-receptor blocking drugs have also been found to be completely without effect on the basal heart rate (Frick, Elovainio, and Somer 1967; Ekblom, Kilbom, and Soltysiak, 1973). Except for the heart rate, none of the variables studied at reinvestigation 72 hours after omission of the drug showed any significant changes compared with the results at the first investigation before the long-term therapy. The lack of acute propranolol effects was a general finding at the reinvestigation. Neither cardiac output nor vascular resistance was changed when a large dose of propranolol was administered intravenously. This general lack of effect might, however, be secondary to the lack of effect on heart rate. As described previously by several authors and discussed above, the bradycardia at beta-receptor blockade is probably of great importance as the mechanism underlying most of the other haemodynamic effects.

The lack of propranolol effect on the heart rate after long-term treatment seems to mimic a persistent beta-receptor blockade. This finding could 
be explained easily if 72 hours were too short a time for the elimination of propranolol from the heart tissue and its beta-receptors. The blood concentrations of propranolol were not measured in this study. However, previous pharmacological studies on the metabolism and elimination of propranolol from the body and from the heart have shown unequivocally that no active substance could be detected after 48 hours (Faulkner et al., 1973).

The increased blood pressure in the pulmonary artery during exercise was one of the acute effects of propranolol injection which was only slightly reduced after long-term therapy with the drug. This indicates that during beta-receptor blockade the pressure work for the right ventricle was augmented in these patients. It is not known for certain whether this increased right ventricular load has any clinical consequences. However, except for patients with incipient heart failure, no previous clinical study seems to have identified right ventricular insufficiency as a major or regular complication during long-term treatment with beta-receptor blocking drugs.

In conclusion, this investigation has shown that in male patients with moderate hypertension, propranolol elicits acute haemodynamic effects at rest and during exercise which are probably secondary to the well-known negative chronotropic and inotropic effects of the drug. These effects were abolished or considerably reduced after oral treatment with propranolol. Furthermore, a previously unknown persistence of a relative bradycardia after withdrawal of long-term therapy with propranolol has been shown. On the basis of these findings a new concept is suggested for the mechanisms underlying the antihypertensive effect involving long-lasting inhibition of the beta-adrenergic receptors.

\section{References}

Adair, J. R., and Manning, J. W. (1975). Hypothalamic modulation of baroreceptor afferent unit activity. American fournal of Physiology, 229, 1357.

Åström, H. (1968). Haemodynamic effects of beta-adrenergic blockade. British Heart fournal, 30, 44.

Brundin, T., and Cernigliaro, C. (1975). The effect of physical training on the sympathoadrenal response to exercise. Scandinavian fournal of Clinical and Laboratory Investigation, 35, 525.

Ekblom, B., Kilbom, A., and Soltysiak, J. (1973). Physical training, bradycardia, and autonomic nervous system. Scandinavian fournal of Clinical and Laboratory Investigation, 32, 251.

Ekelund, L-G., and Holmgren, A. (1967). Central hemodynamics during exercise. Circulation Research, 20-21, Suppl. 1, 33.

Faulkner, S. L., Hopkins, J. T., Boerth, R. C., Young, J. L., Jellett, L. B., Nies, A. S., Bender, H. W., and Shand, D. G. (1973). Time required for complete recovery from chronic propranolol therapy. New England fournal of Medicine, 289, 607.
Fine, J., and Seligman, A. M. (1943). Traumatic shock IV. A study of the problem of the 'lost plasma' in hemorrhagic shock by the use of radioactive plasma protein. Fournal of Clinical Investigation, 22, 285.

Frick, M. H., Elovainio, R. O., and Somer, T. (1967). The mechanism of bradycardia evoked by physical training. Cardiologia, 51, 46.

Frohlich, E. D., Tarazi, R. C., Dustan, H. P., and Page, I. H. (1968). The paradox of beta-adrenergic blockade in hypertension. Circulation, 37, 417.

Furchgott, R. F. (1972). The classification of adrenoceptors (adrenergic receptors). An evaluation from the standpoint of receptor theory. In Catecholamines, p. 283. Ed. by $\mathbf{H}$. Blaschko and E. Muscholl. Handbuch der experimentellen Pharmakologie, 33. Series Editor, K. W. A. Hefter. Springer, Berlin.

Holmgren, A., and Ovenfors, C. O. (1960). Heart volume at rest and during muscular work in the supine and in the sitting position. Acta Medica Scandinavica, 167, 267.

Holmgren, A., and Pernow, B. (1959). Spectrophotometric measurement of oxygen saturation of blood in the determination of cardiac output. A comparison with the van Slyke method. Scandinavian fournal of Clinical and Laboratory Investigation, 11, 143.

Kjellberg, S. R., Rudhe, U., and Sjöstrand, T. (1949). The amount of hemoglobin and the blood volume in relation to the pulse rate and cardiac volume during rest. Acta Physiologica Scandinavica, 19, 136.

Larsson, H., and Kjellberg, S. R. (1948). Roentgenological heart volume determination with special regard to pulse rate and the position of the body. Acta Radiologica, 29, 159.

Metropolitan Life Insurance Company (1959). Statistical Bulletin, No. 40.

Nickerson, M. (1949). The pharmacology of adrenergic blockade. Pharmacological Reviews, 1, 27.

Prichard, B. N. C., and Gillam, P. M. S. (1966). Propranolol in hypertension. American fournal of Cardiology, 18, 387.

Prichard, B. N. C., and Gillam, P. M. S. (1969). Treatment of hypertension with propranolol. British Medical fournal, $1,7$.

Pritchard, W. H., Moir, T. W., and MacIntyre, W. J. (1955). Measurement of the early disappearance of iodinated $\left(\mathrm{I}^{131}\right)$ serum albumin from circulating blood by a continuous recording method. Circulation Research, 3, 19.

Scholander, P. F. (1947). Analyses of accurate estimation of respiratory gases in one-half cubic centimeter samples. fournal of Biological Chemistry, 167, 235.

Sjöstrand, T. (1949). The total quantity of hemoglobin in man and its relation to age, sex, body weight and height. Acta Physiologica Scandinavica, 18, 324.

Sleight, P. (1975). Neural control of the cardiovascular system. In Modern Trends in Cardiology, p. 3. Ed. by M. F. Oliver. Butterworths, London.

Snedecor, G. L., and Cochran, G. W. (1967). Statistical Methods, 6th ed. Iowa State University Press, Ames, Iowa.

Tarazi, R. C., and Dustan, H. P. (1972). Beta adrenergic blockade in hypertension. American fournal of Cardiology, $29,633$.

Tibblin, G., and Åblad, B. (1969). Antihypertensive therapy with alprenolol, a $\beta$-adrenergic receptor antagonist. Acta Medica Scandinavica, 186, 451.

Ulrych, M., Frohlich, E. D., Dustan, H. P., and Page, I. H. (1968). Immediate hemodynamic effects of beta-adrenergic blockade with propranolol in normotensive and hypertensive man. Circulation, 37, 411.

Requests for reprints to Dr. T. Brundin, Department of Clinical Physiology, Serafimer Hospital, S-112 83 Stockholm, Sweden. 